\title{
THE EFFECT OF TRANSFERING ISRAEL CAPITAL CITY TO JERUSALEM TOWARD INDONESIA MACRO ECONOMY
}

\author{
Liliek Nur Sulistiyowati \\ liliek1702@gmail.com \\ PGRI University Madiun
}

\begin{abstract}
ABSTRAK
Presiden Amerika Serikat Donald Trump mengeluarkan kebijakan kontroversial dengan mengakui Yerusalem sebagai Ibukota Israel. Dampak politik dari kebijakan tersebut berimbas pada perekonomian global. Bursa-bursa efek dunia langsung bereaksi, diantaranya jatuhnya bursa saham di Asia. Dampak kebijakan tersebut juga berimbas terhadap perekonomian Indonesia. Kebijakan tersebut memicu kenaikan nilai tukar US\$ terhadap Rupiah. Pengaruh negatif lainnya adalah terjadinya kenaikan harga minyak mentah dunia. Kenaikan harga minyak mentah dunia memberikan beban fiskal APBN. Subsidi BBM pada APBN meningkat seiring dengan peningkatan harga minyak mentah dunia. Kebijakan tersebut juga berpengaruh terhadap tingkat inflasi dan SBI, Sepanjang 2018, Bank Indonesia telah menaikkan SBI sebesar 150 basis poin atau 1.5\%. Penetapan SBI yang tinggi berpengaruh untuk mengurangi tekanan inflasi. Penelitian ini bertujuan untuk melihat pengaruh pemindahan Ibukota Israel ke Yerusalem terhadap variabel ekonomi makro Indonesia yaitu tingkat inflasi, SBI dan nilai tukar rupiah terhadap US\$. Metode Oneway ANOVA dipergunakan sebagai metode analisis pada penelitian ini. Data penelitian yang dipergunakan adalah laporan bulanan Bank Indonesia mulai Januari 2017 sampai dengan Desember 2018. Hasil penelitian yang diperoleh adalah terdapat pengaruh pemindahan Ibukota Israel ke Yerusalem terhadap indikator makro ekonomi Indonesia yaitu tingkat inflasi, SBI dan nilai tukar rupiah terhadap US\$.
\end{abstract}

Kata kunci: donald trump, inflasi: suku bunga SBI; nilai tukar atau kurs.

\begin{abstract}
United States President, Donald Trump, issued a controversial policy recognizing Jerusalem as the Capital of Israel. The political impact of these policies has an impact on the global economy. World stock exchanges immediately reacted, including the fall of stock exchanges in Asia. The impact of these policies also impacted the Indonesian economy. The policy triggered an increase in the exchange rate of US\$ against the Rupiah. Another negative effect is the increase in world crude oil prices. The increase in world crude oil prices impose a fiscal burden on the state budget. The fuel subsidy in the state budget has increased along with the increase in world crude oil prices. The policy also affects the inflation rate and SBI. Throughout 2018, Bank Indonesia has raised SBIs by 150 basis points or 1.5\%. Determination of high SBI has an effect to reduce inflationary pressures. This study aims to look at the effect of moving the Israeli capital to Jerusalem on Indonesian macroeconomic variables, namely the inflation rate, SBI and the exchange rate of the rupiah against US \$. Oneway ANOVA method was used as the method of analysis in this study. The research data used is the monthly report of Bank Indonesia from January 2017 to December 2018. The research results obtained are that there is an influence of the move of the Capital of Israel to Jerusalem on Indonesian macroeconomic indicators, namely the inflation rate, SBI and the exchange rate of the rupiah against US\$.
\end{abstract}

Key words: donald trump; inflation; SBI; exchange rates.

\section{INTRODUCTION}

Some time ago the president of the United States, Donald Trump issued a very controversial statement regarding the recognition of Jerusalem as the capital of Israel. This caused a reaction from leaders round 
the world. The UNSecurity Council condemned Donald Trump's decision, because the transfer of the Israeli capital to Jerusalem was a violation of international law and violations of the United Nations resolution. President Joko Widodo strongly condemned the recognition. The Indonesian government strongly condemned President Donald Trump's policy to move the capital Israel from Tel Aviv to Jerusalem. President Joko Widodo said Donald Trump's policy would disrupt security stability and the peace process between Israel and Palestine. President Joko Widodo also continued his support for Palestine during Donald Trump policy.

Besides having an impact on politics, The policy of moving the Israeli capital to Jerusalem also has a major effect on the economy. As soon as Donald Trump announced the policy, the Stock Exchange in the world reacted immediately, for example affected the fall of the index of stock exchanges in Japan and South Korea, because of investors concerns.

This condition also automatically affects the Indonesian economy. The Director of the Indonesia Stock Exchange (IDX) stated that Donald Trump's policy of admitting Jerusalem as the capital of Israel could affect financial markets and capital markets. (Harjanto, 2017). The United States policy will affect global markets including Indonesia, considering that United States is a country that has a large economic power in the world. The United States policy can also influence the strengthening of the US \$ exchange rate against other currencies, including Rupiah. If it happens, this condition must be carefully monitored because it will have a direct impact on Indonesia's finance and economy. The impact of the strengthening United States capital market toward Trump's policy has an effect on the strengthening of the US Dollar against other currencies.

Director of PT. The Indonesia Stock Exchange (IDX) also said that Jerusalem's declaration of recognition as the capital of
Israel could also affect indirectly the financial markets due to volatile currency values due to the impact of the strengthening of the US dollar, around $50 \%$ of the short-term money, which mean that money was easy to move, so that the movement will affect the currency, and this will have an impact on the inflation rate.

Trump's controversial policy about Jerusalem as the capital of Israel also has a negative influence on the Indonesian economy. Recognition of Jerusalem as the capital of Israel will increase the potential for conflict in the Middle East which will affect world oil production (Simorangkir, 2017). The conditions mention above will cause world oil prices increasing, while oil and energy subsidies in the State Budget (APBN) 2018 are not expected to be able to support the fluctuations in world oil prices. Indonesia currently has the status of an oil importer country, is no longer an oil exporter, will be affected by the increase in world oil prices.

But on the other hand, Trump's policy will also have a positive impact to Indonesian economy. The United States President admission also received a response from several officials in Indonesia, especially related to its impact on the Indonesian economy, the Head of the Fiscal Policy Office of the Ministry of Finance said that he would continue to monitor developments and will continue coordinate with Bank Indonesia, the Financial Services Authority and the Financial System Stability Comittee (Winarto \& Quddus, 2017 ). Indonesia will periodically monitor closely the development of current issues and pay attention to Indonesia's economic fundamentals including inflation, economic growth and foreign exchange reserves and the financial system.

This research is different from previous studies that have been conducted. This research combines aspects of international political policy and its influence on a country's macroeconomic conditions. In general, other existing studies aim to determine the effect of a country's economic policy on the country's macroeconomic 
conditions. For example the effect of the policy setting SBI interest rates on inflation and the exchange rate of the rupiah (exchange rate). In other studies usually see the effect of inter-state economic cooperation policies on a country's macroeconomic conditions. For example the effect of export and import policies between countries on inflation rates, interest rates and the exchange rate of the rupiah (exchange rate).

This study includes international political policy as a research variable in this case the transfer of the Israeli capital to Jerusalem. The international political policy applied by the US superpower to Indonesia's macroeconomic conditions is also different from this research compared to other studies. Another different aspect of this research is highlighting the policy of the current President of the United States Donald Trump, and its influence on the Indonesian economy. Donald Trump is a figure of the President of the United States who often issues controversial political and economic policies, so that the policies implemented affect the global economy, including Indonesia.

The background of the problem above underlies the formulation of the problem in research. Does Donald Trump's admission of Jerusalem as the capital of Israel affect Indonesia's macroeconomic indicators including inflation, SBI interest rates and the exchange rate of the rupiah against the US \$?

The expected outcome of this research is to determine the effect of Donald Trump's admission of Jerusalem as the capital of Israel on Indonesia's macroeconomic indicators including inflation, SBI interest rates and the exchange rate of the rupiah against US \$

\section{THEORITICAL REVIEW}

\section{Previous Research}

(Dwi, 2010), Fundamental Macro economics Factors Impact and Oil Prices on the LQ45 Stock Index in the Short and Long Term. Independent variables include 3 (three) macro economic fundamental variables: economic growth, SBI interest rates and exchange rates (exchange rates) plus oil price variables. Dependent variable LQ 45. The test using Error Correction Model. Economic growth and crude oil prices affect the LQ 45 stock price index in the long term, and economic growth, SBI interest rates affect the LQ 45 stock price index in the long term.

(Purnamawati, Ayu, \& Sri, 2013), Effects of Macro economic Fundamental Factors on Stock Prices. Economic growth independent variable, rupiah exchange rate and SBI interest rate. The LQ 45 stock price index as Variable dependent. Using Error Correction Model (ECM). In the short and long term, economic growth and SBI interest rates negatively affect the LQ 45 stock price index. In the short and long term, the inflation variable has a positive effect on the LQ 45 stock price index. In the short term, the exchange rate variable has a negative effect, while in the long run it has a positive effect on the LQ45 stock price index.

(Linda, 2015), Influence of SBI Rates, Rupiah Exchange Rates and Inflation on Corporate Financial Performance Before and After Privatization (Study at PT Telekomunikasi Indonesia, Tbk. Independent variable: SBI interest rates, rupiah exchange rate and inflation. Dependent variables company financial performance. Methods using Multiple Linear Regressions and Paired Sample $T$ Tests). Before the period of corporate privatization, interest rate variables have an effect on the company's financial performance, while the rupiah exchange rate and inflation variables have no effect on the company's financial performance. The privatization of the company period before and after, shows all the independent variables have a significant effect on the performance of the company. There is no significant difference between financial performance before and after privatization.

\section{Inflation}

Inflation is a condition that there is a gradual increase in prices (Muzakky, Suhadak, \& Topowijoyo, 2015). Inflation can occur anywhere which is a monetary 
phenomenon that monetary growth occurs excessively and is unstable (Muzakky et al., 2015). Inflation indicators in Indonesia are measured based on the results of a survey from the Central Statistics Agency (BPS). Inflation is measured by the Consumer Price Index (CPI) indicator.

According to (Samuelson, Nordhaus, \& Carvallo, 2004) states "Inflation occurs when the general level of prices is rising" (Inflation occurs when the average price in general increases). Inflation also occurs when the average price in general increases continuously (Nopirin, 2007). Measuring the inflation rate generally uses a price index. The most commonly used price index is the wholesale price index and the cost index life (consumer price index), and GNP deflator. To measure inflation, the following formula is used:

whereas:

$$
\text { Inflation }=\frac{I H K n-I H K n-1}{I H K n-1} \times 100 \%
$$

IHKn : consumer index price now

IHKn-1 : consumer index price now minus 1

Sumber: (CaraHarian.com, 2019).

The large trade index measures the rate of inflation by using a number of commodities to a certain extent in large traders, so that the calculation includes the prices of raw materials, raw material prices and prices of finished goods. Meanwhile measurement of inflation rate with GNP deflator by calculating the value of goods and services including net income (GNP), using the formula:

GNP deflator $=\frac{\text { GNP Nominal }}{\text { GNP Riil }} \times 100$

Types of inflation are classified into several criteria (Boediono, 2013):

a. Based on severity: Light category (inflation $<10 \%$ a year). Medium category (inflation between $10-30 \%$ a year), heavy category (inflation between $30-100 \%$ a year), and hyperinflation (inflation 100\% a year). b. Based on the causes:

1. Demand pull inflation, the economy has not yet reached full employment, but there is an increase in total demand so that prices and production increases, which will increase government spending by printing new money.

2. Cost Push inflation, a condition where prices increase but production decreases, so that there is a decline in total supply.

c. If viewed based on the origin of inflation:

1. Inflation originating from within the country (domestic inflation), usually inflation comes from the budget deficit,

2. Inflation originating from abroad (imported inflation), usually sourced from price increases that occur abroad.

Inflation occurs if there are symptoms of price increases that occur continuously. Prices increasing for one or two commodities types cannot be said as inflation unless the commodity price increase widespread and causes an increasing of other goods price.

The main cause of inflation is the excess supply of money compared to the demand for money in society (Ronaldo, 2019). Inflation occurs if the money supply exceeds economic growth. Currency value is determined by the amount of currency in circulation. If Bank Indonesia decides to put more money into the money market, the value of money may fall due to changes in public perception of the value of the currency. The less currency in circulation, the more valuable the currency. When Bank Indonesia decides to print a new currency, basically it aims to reduce the value of money that has been previously circulated (Sugi, 2018).

The next cause of inflation is the amount of national debt. If a country has a high national debt, this is a bad condition for the country concerned. Is high national debt will also drive higher inflation rates? When the state debt increases, there are 2 (two) solutions that must be done to pay off the debt, namely by increasing taxes or printing 
more money. If taxes are raised, business entities in the country will react by increasing the price of the product or service. This is done to offset the amount of the tax increase set. The increase in the price of the product or service will trigger inflation. Meanwhile, if Bank Indonesia takes the second alternative step by printing more money, then the option will cause an increase in the money supply. As mentioned earlier an increase in the amount of money in circulation will also encourage inflation (Sugi, 2018).

The next cause of inflation is the demand pull effect and cost pull effect. If salary increase in an economic system (in a country that is growing and has a low unemployment rate) then people will have more money to spend on the needs of consumer goods. This condition is called demand pull effect. As a result there is an increase in demand for products or services due to an increase in liquidity and demand for consumer goods. Because demand increases, producers will increase prices borne by consumers. This price increase will encourage inflation. Another factor causing inflation is called the cost push effect (cost full effect). This condition is motivated by companies that have increased input costs such as raw materials or direct labor costs. So to maintain company profitability, price increases must be made to consumers due to an increase in production costs borne by producers. This price increase drives inflation.

\section{Interest Rates}

Interest is the amount of costs that must be paid by the borrower to the lender as a service for the use of funds (Muzakky et al., 2015). The amount of money given based on the unit of time is called the interest rate (Muzakky et al., 2015). Meanwhile another opinion states that the interest rate is the percentage of principal time per unit.

To control the money supply, Bank Indonesia operates an open market operation mechanism which is a money market transaction through the sale and purchase of government securities. Bank Indonesia issues Bank Indonesia Certificates (SBI) in the form of securities, which are forms of acknowledgment of debt in rupiah. Bank Indonesia sets the SBI interest rate, which is generally used as a reference for the rate of return that investors will get if they want to invest in risk-free investments.

Policy interest rates that reflect monetary policy responses and attitudes determined by Bank Indonesia as the central bank and are publicly announced periodically are referred to as the SBI or BI rate. BI Rate Announcement is made by the Board of Governors of Bank Indonesia in each Board of Governors' Meeting every month. This BI Rate policy is implemented in monetary operations by Bank Indonesia through the management of liquidity on the money market to achieve desired targets. The operational objectives of monetary policy implemented by Bank Indonesia can be reflected through developments in overnight interbank money market interest rates, developments in deposit rates and ultimately in bank lending rates (Munawaroh \& Handayani, 2019).

Bank Indonesia applies monetary policy through the application of interest rates. In implementing monetary policy, Bank Indonesia uses inflation as the main target (Inflation Targeting Framework/ITF). To achieve the stability of the rupiah exchange rate against foreign currencies, Bank Indonesia adopts a free floating system. When inflation exceeds the target set, Bank Indonesia will raise the SBI/BI rate, otherwise if inflation falls below the target set, Bank Indonesia will reduce the SBI/BI Rate. (Munawaroh \& Handayani, 2019)

One indicator someone will invest is the interest rate (Boediono, 2012). In addition, the interest rate is the "price" that must be paid in the event of an "exchange". According to Marshal Principle (Marshall, 2009) "Interest is the price of capital in the market and usually leads to a balance so that between interest rates and inventories tend to be the same". In accordance with classical 
theory, interest is the price of loanable funds and according to Keynes, the interest rate is a monetary phenomenon. High interest rates will easily attract investors in investing in banks that tend to have a lower risk than other sectors. Therefore the inflation rate tends to be more controlled through the application of interest rates. (Jonathan, 2019)

Note:

$$
\text { Bunga Perbulan }=(\mathrm{P} \times 1 \times \mathrm{t}) / \mathrm{jb}
$$

$\mathrm{P}$ : Basic Fund

1 : The loan risk amount / interest rate

jb : Payment schedule

$t$ : yearly interest

\section{Exchange Rate}

The unit price of foreign currency in the domestic currency is called the exchange rate or exchange rate (Muzakky et al., 2015). For example, the exchange rate of the Rupiah (IDR) to the US Dollar (US \$) is the price per unit of the United States Dollar in Rupiah (IDR). The exchange rate position is important because the foreign exchange rate greatly influences the price of goods produced domestically to be sold abroad. It also includes the costs of goods imported from abroad to be purchased in a domestic country. If a country's currency appreciates (its value increases relative to other countries' currencies), the products produced by that country are relatively more expensive, while foreign products in the country become cheaper, with assuming constant domestic prices in both countries. In the other hand, if a country's currency depreciates (decreases relative to other countries' currencies), then the country's goods abroad become cheaper and foreign goods in that country become more expensive. (Munawaroh \& Handayani, 2019).

According to (Samuelson et al., 2004) the exchange rate is the foreign exchange rate in units of other countries' currencies. The indicator of foreign currency is the foreign exchange market traded on the money market.
A high exchange rate happens if the currency demands increas or decreas against the offer. The midpoint of the USD/IDR BI exchange rate indicator is the reference rate (Indonesia, 2013). So far The US dollar has been an international currency with a very strong position, so many countries use it in international transactions. According macro theory, exchange rates and stock prices are positively related. To calculate the exchange rate or middle rate:

$$
\text { Middle rate }=\frac{\text { selling rate }+ \text { buying rate }}{2}
$$

Types of exchange rates:

1. Selling rate, value of sale of foreign exchange determined by the bank,

2. Middle rate, value of the middle exchange rate, calculated between the selling rate and the buying rate,

3. Buying rate, value for purchasing foreign exchange,

4. Flat rate, rate normally used in the traveler check purchase of a or bank note (Fischer, Lieberman, \& Adams, 1981)

The exchange rate (exchange rate) along with the inflation rate have a longterm relationship with the stock returns (Kwofie \& Ansah, 2018). The exchange rate is also the most important indicator of a country's economic growth. Changes in exchange rates will have a significant impact on international trade (Ali, Bashir, \& Mahmood, 2015). Hyder and Shah, 2004, the exchange rate also has an important and very decisive role in the trade of the global market economy. The economies of developing countries, including Indonesia, are generally open to international trade. Therefore the domestic inflation rates of developing countries cannot be protected from external price shocks such as those from imported goods prices or appreciation/depreciation of the domestic currency exchange rate (Malik, Ajmal, \& Zahid, 2017). Therefore the issue of exchange rates is one of the economic 
strategies that are analyzed, manipulated and observed by a country's government.

\section{The Relationship of Indonesian Foreign Policy and Its Impact on the National Economy}

Implementing foreign relations is an effort to increase national economic growth. The existence of political interference in the government of the country will result in cooperation or agreement with the international world.

Indonesia's foreign policy can have both positive and negative impacts on the economy. One form of Indonesia's foreign policy in the international world is the joining of Indonesia in the United Nations (UN). Indonesia is a member of the United Nations which has an active role in the organization. The joining of Indonesia as a member of the United Nations so far has had a positive impact on the national economy. One of the advantages of joining Indonesia as a member of the United Nations for the national economy is the existence of loan assistance from the International Bank under the auspices of the United Nations for Indonesia. Financial assistance from the International Bank under the auspices of the United Nations helped to encourage the implementation of economic programs planned by the Government of Indonesia.

Indonesia is also incorporated in the G20 group countries. By joining the G-20 organization, one form of positive contribution is Indonesia in conducting economic cooperation with other G-20 member countries, including in efforts to attract investors from G-20 countries to invest in Indonesia.

Through UN and G-20 organizations, Indonesia is also active in various international economic cooperation. For example ACFTA (ASEAN-China Free Trade Agreement) cooperation. The Indonesian government has ratified the ACFTA agreement through the issuance of Presidential Decree No. 48 of 2004. The agreement includes a free trade agreement between the ASEAN countries and China (China). The agreement entered into force on January 1, 2010. The ACFTA agreement aims to create an ASEAN and China free trade area with a commitment to eliminate and reduce barriers to trade between countries in the form of tariffs and reductions and non-tariff reductions, expand market access, simplify regulations and investment provisions, and efforts to enhance economic cooperation between ASEAN countries and China. The background underlying the ACFTA agreement is an effort to advance the economies of countries in ASEAN and China. Through this agreement it is hoped that there will be increased cooperation between business people in the ASEAN countries and China by forming strategic alliances. For Indonesia, it is hoped that the ACFTA agreement will increase market access for Indonesia's superior products to the markets of ASEAN countries and China. Through the ACFTA agreement it is hoped that technology transfer can occur between business actors in ACFTA participating countries including Indonesia.

Agreements or cooperation with the international community will result in events occurring in any part of the world that will directly or indirectly impact Indonesia. Political conditions that occur in a country will affect economic conditions in Indonesia. There has recently been tension between Saudi Arabia and Yemeni rebels, which was preceded by a drone attack on the largest Aramco oil refinery in Saudi Arabia. Not to mention this conflict also involves Iran which is behind Yemeni rebels.

Crisis in countries in the Middle East usually have an impact on the global economy. Middle Eastern countries in general are world oil producers. Drone strikes at Aramco refineries have halved the total oil production in Saudi Arabia. As we know, Saudi Arabia is a supplier of crude oil to a number of countries in the world, including Indonesia (Rahmah, 2019). Reduced world oil production in Saudi Arabia will result in a reduction in world oil supply to the entire world including to Western countries. For Indonesia, the trade balance of the oil and 
gas sector has the potential to become increasingly burdened after the drone attack that blew up the Saudi Aramco oil refinery. The explosion of the Saudi Aramco refinery will disrupt global oil supplies, and if the damage conditions at the Saudi Aramco refinery are not resolved immediately, this will result in a reduced supply of oil. The reduced supply of oil will cause a surge in world oil prices on the international market.

For Indonesia, the increase in world oil prices will have a negative impact on the trade balance. Indonesia is currently an oil importer, with the increase in world oil prices it will make the import burden on Indonesia's trade balance swell.

Data shows that not too long after the Saudi Aramco refinery explosion, world oil prices jumped significantly. The increase in world oil prices reached almost $15 \%$. The price of crude oil Brent which has become an international benchmark rose $14.6 \%$ to US \$ 69.02 per barrel, while the price of crude oil in West Texas Intermediate (WTI) which has been the benchmark in the United States rose $14.7 \%$ to 62.90 per barrel (Rahmah, 2019). Disruptions to the Saudi Aramco refinery have caused the world to lose oil supplies of 5.7 million barrels per day, equivalent to $5 \%$ of world oil production.

This condition has the potential to widen the oil and gas deficit at the end of 2019. Until August 2019, according to data from the Central Statistics Agency (BPS) the magnitude of the oil and gas balance deficit reached US $\$ 5.68$ billion. Widening the oil and gas balance deficit will have a domino effect, including the current account deficit will reach 3\% of the Gross Domestic Product (GDP). The increase in world oil prices will also affect the real sector, including by increasing production and logistics costs in the real sector. As a result, producers will increase the selling price, while on the one hand the purchasing power of the people will decline.

Soaring world oil prices will also affect global investment instruments. The crisis in the Middle East region affected the move- ment of world stock prices. Global stock exchanges fell due to tensions in the Middle East region.

The trade war between the United States and China also had a significant economic impact on Indonesia's macro economy, bearing in mind that the United States and China are one of the major economic forces in the world today.

This policy originated from President Donald Trump's policy related to the policy of raising import tariffs for products from China. An import duty of $20 \%$ was applied for 1.2 million large-sized washing machine products and a $50 \%$ import duty tariff for washing machines larger than that size in the first year. The application of import duty will decrease by $16 \%$ and $50 \%$ after entering the third year (Mirzayev, 2019). In the first year import tariffs for solar cells and modules were increased to $30 \%$, and only reduced to $15 \%$ after the fourth year. President Trump also issued a policy of import duty of $25 \%$ for steel products and $10 \%$ for aluminum products. The dumping policy for steel and aluminum products as a sign that foreign companies move their facilities to the United States. President Trump said that this policy was issued to protect workers in the United States. During the 2016 US Presidential Election campaign, President Trump promised to restore the glory of the US steel and aluminum industry. President Trump also added the amount of additional import tariff specifically for products from China amounting to 100 billion US \$.

Trump's policy is also motivated by the condition of the budget deficit that is increasingly getting bigger in the United States. President Trump considers that economic globalization is very detrimental to the United States. International trade practices between China and international trade partners have always positioned China as a country that has been benefited so far. China always experiences a trade surplus in every international trade transaction (Harjanto, 2017). China in 2017 was the largest contributor to the deficit for the United States. US 
International Trade Commission (USTC) data for 2017 shows China's contribution to the US budget deficit of -375 billion US \$.

President Trump's policies above have a negative impact on China. This is due to China's biggest income derived from import and export activities. Trump's policy directly reduces the amount of foreign exchange for China. The Chinese government under President Ji Xinping did not remain silent and carried out a retaliatory policy against the policy of the United States Government. A counter policy that automatically triggers a trade war between the two world economic giants today.

The US tariff policy is reciprocated by a similar tariff policy by China for US products. The Chinese government issued a policy of imposing import duties on US pork products by $25 \%$. It also imposed a $15 \%$ import duty on steel, fruit and wine products. The Chinese government also imposed an increase in import duty tariffs for 128 products that will enter China (Setiawan, 2018). These products include steel, ethanol, wine, ginseng, fresh fruit and dried fruit. Tariff policy imposed by China will hit US agricultural products, especially soybeans.

The trade war between the United States and China is actually motivated by the economic interests of each country. On one hand Trump is pursuing protectionist policies to protect US domestic interests in accordance with his campaign promises during the 2016 US Presidential Election. While China is also protecting its economic interests from being disturbed by protectionist policies. The policy of the United States of America is considered a threat to the Chinese economy, where most of its foreign exchange is derived from exports and imports.

The rise of China's economy in the past decade also shows the existence of China as a new world economic giant. The position of the United States as a world superpower can be threatened by the rise of the Chinese economy. The position of the United States and China as the superpower of the world economic power automatically affects the global economy of the world. The trade war between China and the United States will affect the economies of other countries in the world including Indonesia. The United States and China are Indonesia's two main trading partners (Mustami, 2017).

Data for 2017 shows that Indonesia's exports to China amounted to $13.7 \%$, while Indonesia's exports to the United States amounted to $10.6 \%$. If accumulated, Indonesia's total export value to China and the United States will reach $24.3 \%$ of Indonesia's total exports to the entire world. The two countries as mentioned earlier are Indonesia's main trading partners in international trade.

The United States is the biggest contributor to Indonesia's trade surplus in recent years. Indonesia and the United States trade balance in the last 5 years from 2013 to 2017 always has a surplus, from 6.63 billion US \$ in 2013 to increase to 9.67 billion US \$ in 2017.

Besides the United States, China is also Indonesia's largest trading partner. Indonesia's trade relations with China are also quite large, although the trade balance between Indonesia and China places Indonesia in a deficit position. The data shows the trade deficit between Indonesia and China of -7.24 Billion US \$ in 2013 increased to - 12.68 Billion US \$ in 2017.

\section{President Donald Trump's Policy and Its Impact on the Indonesian Economy}

The United States is a superpower that has political power in the international arena. Every political and economic policy adopted by the United States is certain to have an impact on other countries in the world. In the 2016 US presidential election, Donald Trump was elected as the 46th President of the United States. After being elected president, Donald Trump often made controversial policies that had an influence on the global economy.

Some of the policies implemented by President Donald Trump that have an influence on the Indonesian economy inclu- 
de the reduction of tax rates, the implementation of rate policies, restrictions on imports to the United States up to the occurrence of trade wars between the United States and China. President Donald Trump's policy to cut tax rates from $35 \%$ to only $21 \%$ has an impact on increasing investment into the United States. Policies known as Trump Taxes will attract many investors to invest in the United States.(Fauzia, 2018)

The cut in tax rates has encouraged positive perceptions of investors to invest in the United States. On the other hand this policy will make other countries especially developing countries less attractive, as a result capital flows will return to the United States (Kota, 2017 ). In the period January to July 1998 it was estimated that 157 trillion funds had been released from Indonesia back to the United States. This condition makes the US \$ exchange rate getting stronger.

One of Trump's most controversial policies is the trade rates enforcement. Several countries have been targeted by this trade rate policy, including China, the European Union, Mexico and Canada.

Those countries have became victims of the United States rate policy. Indonesia Indirectly is also affected by the normalization of rate policies implemented by the United States. Currently the United States is reviewing countries that accept cuts in import duties (Generalized System). Preferences/GSP). GSP is a United States policy in the form of cutting import duties, where Indonesia is one of the countries that accepts the GSP policy. This GSP policy highly drives Indonesian exports to the United States. If GSP policy is withdrawn or eliminated it, will have a significant impact toward Indonesian exports level to the United States.

Donald Trump is known as a conservative nationalist figure who will protect the trade of US companies by restricting imports to the United States (Fadila, 2016). This condition will result in changes in investor behavior. Investors will move to gold investments compared to other commodity investments. Due to limiting imports policy to the United States implemented by President Donald Trump, it will have an impact on Indonesia's export sector. This is because the United States is one of the biggest destinations for Indonesia's exports.

International political tension, especially in the Middle East region must also receive serious attention from the Indonesian Government. The Middle East Tensions are triggered by US President Donald Trump's policy regarding the transfer of the Israeli Capital to Jerusalem. Negative responses from these policies arise from Islamic countries including Indonesia.

Any tensions in the Middle East will usually trigger crude oil prices increasing (Budimanta, 2017). Bloomberg data at the end of 2017 stated that crude oil prices rose by $0.46 \%$ compared to the previous US $\$$ 57.04 per barrel due to the effects of Trump's policy regarding the transfer Israeli capital to Jerusalem. In the short and medium term, this condition will add to the fiscal burden on the Indonesian government, because there is still a prices subsidy sold in the community. The increase in fiscal freedoms that occur will encourage the increasing deficit of the State Budget (APBN). Indonesian government must anticipate the economic impact of Trump's policy because there will also be potential shocks to the rupiah exchange rate against US \$. As a result of Trump's policy, the rupiah exchange rate against the US \$ getting weaker.

In international millions dollars trade, any small change in exchange rates will have an impact. For export-based businesses, the weakening of the rupiah exchange rate against US \$ will reduce income. Meanwhile, import costs will increase so that it will increase production costs.

\section{Relationship between Inflation Rate and Interest Rates}

One way to neutralize the level of inflation in a country is through setting interest rates (Semuel \& Nurina, 2015). Determination of interest rates is a form of 
monetary policy, reflecting the amount of money circulating in the market (Asgharpur et al., 2007). Interest rates have a negative influence on the level of inflation in a country (Semuel \& Nurina, 2015). The findings of this study are consistent with research conducted by (Kandel, Ofer, \& Sarig, 1996) who found facts of a negative relationship between interest rates and inflation rates. The hypothesis put forward by (Fisher, 1930) also found the fact that interest rates represent fluctuations in inflation.

But there are also findings of other studies that suggest a positive relationship between interest rates and inflation. Research (Semuel \& Nurina, 2015) prove a positive relationship between interest rates and inflation rates. If the interest rate policy increases, the inflation rate will decrease. Other studies were carried out by Mishkin (1988) and Gibson (1982). They find the fact that interest rates have a positive relationship with inflation. Inflation occurs when the money supply is greater than the amount of goods and services offered. Inflation can also occur if the level of confidence in the currency itself has decreased. The condition of loss of confidence in the Rupiah shows that the Rupiah has depreciated against US \$. The study also found that if a high interest rate policy is implemented it will reduce the level of investment (Bernanke \& Kuttner, 2005)

The Relationship between Interest Rates and Exchange Rates and Macroeconomic Conditions of a Country

One of the macro-economic factors that influence the exchange rate (exchange rate) and economic growth is the SBI interest rate. The determination of the SBI interest rate is a decision taken as a reaction to the weakening of the exchange rate. If the rupiah depreciates, Bank Indonesia will raise the SBI interest rate. An increase in SBI interest rates will put pressure on economic growth (Muzakky et al., 2015)

Low interest rates will encourage investment growth which will ultimately increase a country's economic growth. Conversely, high interest rates will reduce the level of investment in a country which will ultimately result in economic growth to decline as well (Asnawi \& Fitria, 2018). Interest rates are one indicator that affects a country's macroeconomic conditions both positive and negative.

Generally, interest rates are set by Bank Indonesia to be set low with the aim of increasing economic growth. Determination of low SBI interest rates will affect the increase in liquidity for the banking world which will ultimately encourage economic growth. Increased liquidity funds available in banks will be absorbed by entrepreneurs to increase the production sector. The opposite condition if high interest rates make the source of debt funding more difficult for the production sector. This can result in a decline in the level of corporate profits so that company growth is not as good as when compared to low interest rates.

One form of government intervention in influencing exchange rates (exchange rates) is by moving interest rates. Consumer behavior can be changed by making changes to real interest rates (Muzakky et al., 2015). Setting high interest rates will increase income in savings. Conditions of high interest rates require consumers to reduce their consumption for the current period to be used in the next period. The ups and downs of the level of consumption of a society will affect a country's income. If measured by GDP using the expenditure approach, the ups and downs of public consumption affect the economic growth of a country (Muzakky et al., 2015).

An increase in the value of a currency is caused by a decrease in the money supply. While on the other hand the level of investment and consumption is lower. Conditions like this can be concluded interest rates (interest rates) have a negative effect on the exchange rate (Jordaan, 2013). Other research conducted by Hakkio (1986) and Berument and Gumay (2003) found the fact that an increase in interest rates also affects the 
increase in the exchange rate (exchange rate). An increase in interest rates will increase the attractiveness of the assets. This condition will make the demand for assets will increase. Increasing demand for assets will also increase demand for money (Rush, Hakkio, \& Schmidt, 1996).

The results showed a positive relationship between interest rates and exchange rates (Semuel \& Nurina, 2015). One of the factors causing exchange rate fluctuations is more often caused by non-economic factors that are difficult to predict. One non-economic factor that influences fluctuations in the Rupiah exchange rate is political and security factors in Indonesia.

\section{The Relationship between Inflation Rate} and Exchange Rates and Macroeconomic Conditions of a Country

The success of a country in solving its economic problems can be seen from the country's micro and macro indicators. The study of all activities that discuss a country's economic problems is called macroeconomics (Ronaldo, 2019).

One of the most important macroeconomic indicators to measure the stability of a country's economy is the inflation rate. Changes in the inflation rate will have an impact on economic growth. Rise and fall of the inflation rate will result in economic turmoil in a country.

The inflation rate has a negative influence on a country's economic growth. Increasing inflation will reduce economic growth. This happens because an increase in inflation will encourage an increase in interest rates which will result in a decrease in the level of investment (Asnawi \& Fitria, 2018). Inflation also drives economic instability, a balance of payments deficit, speculative investment which ultimately leads to a decline in the level of people's welfare as an indicator of a country's economic growth decline (Asnawi \& Fitria, 2018).

Increased inflation in certain conditions is a negative signal for investors (Munawaroh \& Handayani, 2019). Inflation will cause an increase in company costs. Inflation rate that is too high (hyperinflation) will reduce the level of prosperity of the community and also reduce people's purchasing power as well.

There is an empirical relationship between the exchange rate (exchange rate) with the level of inflation that occurs in a country. The theory that has been explaining the relationship between the exchange rate and the inflation rate is the purchasing power parity (PPP) theory. The exchange rate balance that is adjusted to the magnitude of the difference in inflation rates between the two countries is called purchasing power parity (Muzakky et al., 2015).

A country that experiences an increase in prices of goods whose currency exchange rates will experience a weakening compared to currencies of other countries that do not experience increases in the prices of goods (Muzakky et al., 2015).

The exchange rate of one country's currency will depreciate against another country's currency due to inflation. In a country that experiences an increase in the price of goods (inflation), the exchange rate (exchange rate) will experience a depreciation of the currencies of other countries where there is no increase in the price of goods or the price of fixed goods. In conditions where there is an increase in goods on domestic or local products or services, consumers will look for products or services abroad (imported) whose prices are cheaper. This causes an increase in demand for foreign currencies to pay for imported products or services. An increase in demand for foreign currencies will cause the local currency to depreciate against foreign currencies (Muzakky et al., 2015).

But not all inflation affects the economic growth and macroeconomic conditions of a country. If there is mild inflation, the inflation rate is below $10 \%$, it even tends to encourage economic growth (Ronaldo, 2019). Mild inflation will encourage entrepreneurs to increase their production. The price increase that occurs will encourage entrepreneurs 
to expand their production with the aim of getting more profit. Increased production will also have a positive impact with the expansion of new jobs that will encourage economic growth.

\section{Thought Framework}

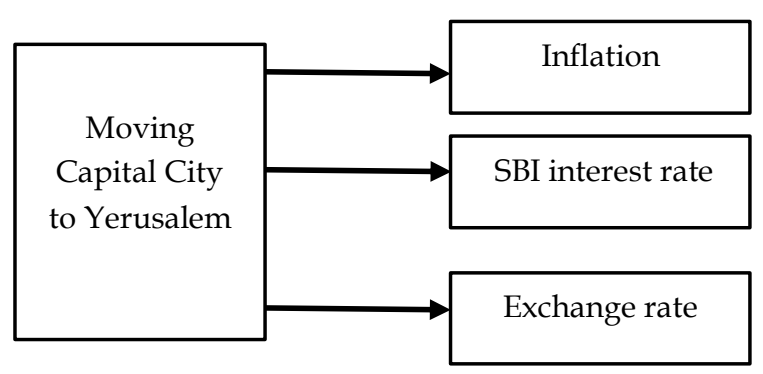

Picture 1

Mindset Research

\section{Hypothesis}

The political and economic policies of the United States always influence other countries in the world. The position of the United States as a superpower in the political and economic fields will always determine the political and economic direction of other countries in the world.

Donald Trump's recognition of Jerusalem as the Capital of Israel had an influence especially on countries in the Middle East and Islamic countries including Indonesia. Donald Trump's policy affects the political conditions and economic conditions of Indonesia.

Social, political and economic turmoil that occurs abroad usually affects the inflation rate of a country (Mankiw \& Gregory, 2007). Donald Trump's policy on recognizing Jerusalem as the Capital of Israel influences the inflation rate in Indonesia. Based on these findings the first hypothesis of the study can be formulated as follows:

$\mathrm{H}_{1}$ : It is suspected the move of the Israeli capital to Jerusalem there is inflation difference.

Political and monetary policy in the United States according to the Governor of Bank Indonesia (BI) is one of the reasons in making policies to change SBI interest rates (Laucereno, 2018). Donald Trump's policy of recognizing Jerusalem as the Capital of Israel influences Indonesia's monetary policy, especially in determining SBI interest rates. Based on these findings the second hypothesis of the study can be formulated as follows:

$\mathrm{H}_{2}$ : Allegedly with the move of the capital to Jerusalem there is a difference in SBI interest rates.

Tensions in the Middle East region will always trigger an increase in crude oil prices (Simorangkir, 2017). Trump's policy regarding the relocation of the Israeli capital to Jerusalem has fueled world crude oil prices. This condition automatically impacted the Indonesian economy. Fiscal burden will increase along with the increase in subsidies to cover the difference in current world crude oil prices by fixing oil prices in the APBN in the short and medium term.

An increase in fiscal free will encourage an increase in the deficit of the State Budget (APBN). This APBN deficit will encourage increased demand for the US \$ currency. Donald Trump's policy regarding recognition of Jerusalem as the Capital of Israel has the potential to cause shocks to the exchange rate of the rupiah against US \$. As a result of Trump's policy, the exchange rate of the rupiah against the US $\$$ is getting weaker. Based on these findings, the third hypothesis of the study can be formulated as follows:

$\mathrm{H}_{3}$ : It is suspected that the movement of the capital city to Jerusalem there is a difference in the exchange rate.

\section{RESEARCH METHODS \\ Data Collection Procedures}

The data used in this study is secondary data. Secondary data is data that is used by researchers in research whose sources are obtained from research or existing data. Data from sources of research come from the Bank Indonesia monthly report. The research period starts from January 2017 to December 
2018. The research period is divided into 2 groups, namely:

- First period, before Israeli capital city moving to Yerusalem, that is from January 2017 through Desember 2017.

- The second period, after the transfer of the Israeli capital to Jerusalem, that is from January 2018 to December 2018.

The testing uses ANOVA method, both data periods before and after the transfer of the Israeli Capital to Jerusalem were independent variables (factor). A distinctive feature in ANOVA testing method is that the independent variables (factors) must be nominal or ordinal.

While the dependent variable (response) in ANOVA testing in this study includes 3 (three) variables, namely:

- Inflation Rate

- SBI inflation rate, and

- Rupiah exchange rate against US \$

The characteristic of the dependent variable (response) in ANOVA testing is that the research data must have a numerical scale (interval or ratio). The analysis used to test the hypothesis from the research data above is one-way ANOVA (Oneway ANOVA)

\section{Technical Analysis}

The analysis technique in this study uses Analysis of Variance (ANOVA). ANOVA is a statistical analysis technique that tests the difference in average in groups (groups). Group (groups) here is the type of treatment. Anova was first introduced by Ronald Fisher. first discovered in 1925, in a book written by Fisher, "Statistical Methods for Research Workers." Anova is a statistical testing procedure that is almost the same as the average difference test ( $t$ test). The advantage possessed by ANOVA test is that it can test the treatment differences of more than two groups. This is different from the average difference test with the $t$ test, which only tests the differences in the average of the two groups.

\section{The ANOVA Hypothesis Testing}

The ANOVA hypothesis testing only uses one type of hypothesis, namely the twoway hypothesis (two tail). The two-way hypothesis test (two tail) means to find out whether there are differences in averages or not, by not testing more specifically where the differences are. The statistical hypothesis used is:

H0: $\mu 1=\mu 2=\mu 3=\ldots=\mu n$; means no difference average $n$ in treatment group $\mathrm{H} 1: \mu 1 \neq \mu 2 \neq \mu 3 \neq \ldots \neq \mu \mathrm{n}$; eans there is difference average $n$ in treatment group

Formula to count $\mathrm{F}$ ( $F$ test) is:

$$
\mathrm{F}=\mathrm{MST} / \mathrm{MSE}
$$

Whereas:

$$
\begin{aligned}
& \text { F : coeffisient ANOVA } \\
& \text { MST :Mean Square Treatment } \\
& \text { MSE :Mean Square Error }
\end{aligned}
$$

Anova is used as an analytical tool to test the research hypothesis whether there are differences in the average between the treatment groups tested. Test statistics for the ANOVA test are F count or F value. Where the decision to test the hypothesis is to compare the calculated $F$ values with the values in Table $\mathrm{F}$ or by looking the significance value of the test obtained. If the calculated $\mathrm{F}$ value is greater than $\mathrm{F}$ table or if the significance value of the test is $<0.05$, then a conclusion can be taken to reject the $H$. The conclusion obtained from Reject Ho is that there is an average difference between each treatment group.

\section{Why using ANOVA?}

Testing the hypothesis using the ANOVA method is based on several considerations below:

1. Facilitate analysis in several different sample groups, while the risk of errors is the smallest.

2. To find out whether there are significant differences between groups one with the other groups. Descriptively it can be 
found that the average difference is numerically large, but based on the ANOVA analysis, the difference can be insignificant, so the average difference must be ignored. Likewise, the descriptive possibility of a difference in average that occurs is small, but based on ANOVA analysis, the difference is significant, so the conclusions obtained there are differences in the average different minimum in one group so that the findings of the average difference between samples groups should not ignored.

The main characteristic in ANOVA is that there are one or more independent variables (factors) and there are one or more non-dependent variables (response), where the response variable is the effect of the existence of a factor variable. The other main feature is the non-dependent variable (response) has a quantitative or numerical scale. The scale of the non-free variable (response) is at least interval or ratio scale. Meanwhile the independent variable (factor) has a category or qualitative scale. The independent variable has a nominal or ordinal scale. The ANOVA test is one type of parametric testing that requires several testing assumptions that must be fulfilled. One of the assumption test that must be fulfilled is that the non-free variable (response) must meet the normal distribution requirements. Fulfillment of the normality requirements for nonfree variables free means that the sample taken is a random sample so that it can represent the entire population under study. So the research results can be generalized.

The type of ANOVA used in this study is one-way ANOVA (Oneway ANOVA). Oneway ANOVA is used because of the number of independent variables and one nonindependent variable.

Some of the assumptions that must be fulfilled in the ANOVA test are as follows:

1. Samples taken in groups/treatments must be mutually independent.

This means that sampling from groups or treatment one does not depend on groups or other treatments.
2. Variance between treatments or groups must be homogeneous

The dependent variable must have the same variance or be homogeneous. To find out the variance homogeneity testing was carried out using the Levene Statistics test

If the significance level of Levene Statistics value is greater than 0.05 , it can be concluded that the variance between homogeneous groups, and in the other hand, if the significance level of Levene Statistics value is smaller than 0.05 , it can be concluded that the variance between groups is not homogeneous.

3. Data for each group is normally distributed.

Normality testing is done on non-independent variables (response). To test the normality of non-dependent variables (response) using the Kolmogorov Smirnov test (K-S test).

Below here are the basic criteria on a decision normality tests using the Kolmogorov Smirnov Test:

1. If the K-S test results in a significance level ( $p$ value) greater than 0.05 , it can be concluded that the non-free variable (response) meets the requirements of normal distribution.

2. Conversely if the K-S test produces a significance level ( $p$ value) smaller than 0.05 , it can be concluded that the non-free variable (response) does not meet the normal distribution requirements.

\section{RESULT AND DISCUSSION}

Model Analysis And Hypothesis Testing

Hypothesis testing uses one-way ANOVA (Oneway ANOVA), where the testing model aims to see whether there are differences in the average in the 2 research groups that are set on the independent variable (factor). In this study 2 groups of independent variables (factors) were the period before and after the transfer of the Israeli capital to Jerusalem.

While the dependent variable (response) includes 3 (three) variables, namely the rate 
of inflation, SBI interest rates and the exchange rate of the rupiah against US \$. This study aims to see the effect of the transfer of the Israeli Capital to Jerusalem on Indonesia macro economic conditions. Macro economic indicators used in this study are the inflation rate, the SBI interest rate and the exchange rate (exchange rate) of the rupiah against US $\$$.
By using the one-way ANOVA method (Oneway ANOVA), the researcher aims to see the effect of moving the capital city of Israel to Jerusalem on Indonesia's macroeconomic indicators, namely SBI interest rates, inflation rates and exchange rates (exchange rates).

Hypothesis testing is done to answer the phenomena above.

Table 1

Descriptif Analysis of the Dependent Variable (Respon)

\begin{tabular}{llccccc}
\hline \multicolumn{1}{c}{ Variabel } & \multicolumn{1}{c}{ Periode } & $\mathbf{N}$ & Average & $\begin{array}{c}\text { Deviation } \\
\text { Standard }\end{array}$ & Min & Max \\
\hline Inflation (\%) & $\begin{array}{l}\text { Before move } \\
\text { to Yerusalem } \\
\text { After move to } \\
\text { Yerusalem }\end{array}$ & 12 & 3.81 & 0.333 & 3.30 & 4.37 \\
& $\begin{array}{l}\text { Before move } \\
\text { to Yerusalem }\end{array}$ & 12 & 4.56 & 0.241 & 4.25 & 4.75 \\
\hline $\begin{array}{l}\text { SBI interest rate } \\
(\%)\end{array}$ & $\begin{array}{l}\text { After move to } \\
\text { Yerusalem }\end{array}$ & 12 & 5.08 & 0.733 & 4.25 & 6.00 \\
\hline $\begin{array}{l}\text { Exchange rate } \\
\text { Rupiah toward }\end{array}$ & $\begin{array}{l}\text { Before move } \\
\text { to Yerusalem } \\
\text { US\$ }\end{array}$ & 12 & 10.237 & 252.31 & 9.880 & 10.580 \\
& $\begin{array}{l}\text { After move to } \\
\text { Yerusalem }\end{array}$ & 12 & 10.551 & 166.17 & 10.160 & 10.750 \\
\hline
\end{tabular}

Source : research data

Table 1 shows a description of the research variables in this case the dependent variable (response), namely the rate of inflation, SBI interest rates and the rupiah exchange rate against US $\$$. The average inflation rate before the transfer of the capital to Jerusalem was $3.81 \%$, while the average inflation rate after the transfer of the capital to Jerusalem by $3.20 \%$. it means there was a decrease in the inflation rate after the transfer of the capital of Israel to Jerusalem compared to before the transfer of the capital of Israel to Jerusalem.

Meanwhile the average SBI interest rate before the transfer of the Israeli capital to Jerusalem was $4.56 \%$, compared to the average SBI interest rate after the transfer of the Israeli capital to Jerusalem by $5.08 \%$. That means an increase in the SBI interest rate after the transfer of the capital of Israel to
Jerusalem compared to before the transfer of the capital of Israel to Jerusalem.

The average exchange rate of the rupiah against US $\$$ before the transfer of the capital of Israel to Jerusalem is amounted to 10,237, while the average value of the rupiah exchange rate against US $\$$ after the transfer of the capital of Israel to Jerusalem is amounted to 10,551 . This means that the value of the rupiah exchange rate against US \$ tends to weaken after the transfer of the capital of Israel to Jerusalem compared to before the transfer of the capital of Israel to Jerusalem. To answer the research hypothesis is there a difference in the average SBI interest rate, inflation rate, and the exchange rate (exchange rate) of the rupiah against US $\$$ before and after the transfer of the Israeli capital to Jerusalem was tested using the Oneway Anova method. Before testing using the 
Oneway Anova method, the assumptions of the ANOVA model were tested.

\section{Normality Test}

The assumption that must be fulfilled from the use of ANOVA method is that the data must follow a normal distribution. Normality Testing uses the KolmogorovSmirnov method (K-S test).

The normality testing results of for each variable can be seen in Table 2 .

Table 2

Normality Test

\begin{tabular}{llccc}
\hline \hline \multicolumn{1}{c}{ Indicator } & \multicolumn{1}{c}{ Note } & $\begin{array}{c}\text { Inflation } \\
\mathbf{( \% )}\end{array}$ & $\begin{array}{c}\text { Interest rate } \\
\text { (SBI \%) }\end{array}$ & $\begin{array}{c}\text { Exchange Rate } \\
\text { Rupiah toward US\$ }\end{array}$ \\
\hline $\mathrm{N}$ & & 24 & 24 & 24 \\
\hline Normal & Mean & 3.51 & 4.82 & 10.394 \\
Parameter & Standar Deviation & 0.400 & 0.597 & 263.55 \\
\hline Most Extreme & Absolute & 0.154 & 0.257 & 0.191 \\
Differences & Positive & 0.154 & 0.257 & 0.100 \\
& Negative & -0.127 & -0.168 & -0.191 \\
\hline K-S test Z & & 0.753 & 1.259 & 0.936 \\
\hline $\begin{array}{l}\text { Asymp Sig } \\
\text { tailed) }\end{array}$ & & 0.623 & 0.084 & 0.345 \\
\hline Da & & & & \\
\hline
\end{tabular}

Data Source : Research data

Based on the normality testing results using the Kolmogorov-Smirnov test as in Table 2 shows each research variable meets the normality requirements of the data. These results can be seen from the results of normality testing using the Kolmogorov Smirnov method for all non-independent variables having a significance level ( $p$ value) greater than 0.05 .

- The inflation rate, the significance level = $0.623>0.05$, meets the normal distribution
- SBI interest rate, significance level = $0.084>0.05$, meets normal distribution

- Exchange rates, significance level = $0.345>0.05$, fulfilling distribution

\section{Variant Homogeneity Test}

The next assumption test that must be fulfilled is the homogeneity variant test from all research data. The indicator of variance homogeneity test uses the value of Levene Statistics. The test results for variance homogeneity can be seen in Table.

Table 3

Variant Homogeneity Test

\begin{tabular}{lcccc}
\hline \multicolumn{1}{c}{ Variable } & Levene Statistics & df1 & df2 & Sig \\
\hline Inflation (\%) & 3.980 & 1 & 22 & 0.089 \\
Interest Rate SBI (\%) & 2.593 & 1 & 22 & 0.146 \\
Exchange Rate & 4.093 & 1 & 22 & 0.055 \\
Rupiah toward US\$ & & & & \\
Source $:$ research data & & & &
\end{tabular}

Based on the results of variance homogeneity testing using the Levenestatistics indicator as in Table 3 shows that each research variable fulfills the variance 
homogeneity test requirements. Conclusions obtained from Levene Statistics testing for all non-free variables (responses) produce a significance value ( $p$ value) greater than 0.05 Tingkat inflasi, taraf signikansi $=0.089>$ 0.05 , varians homogeny.

- SBI interest rate, significance level $=0.146>$ 0.05 , homogeneous variance

- Exchange rate, significance level $=0.055>$ 0.05 , homogeneous variance.

\section{ANOVA Hypothesis Testing}

After the assumption test is fulfilled for the ANOVA method, the next step is to test the hypothesis of the oneway ANOVA model. The testing of the hypothesis model aims to see whether there is an average difference in Indonesia's macro economic indicator variables due to the transfer of the Israeli capital to Jerusalem.
The hypothesis testing model is as follows:

$\mathrm{H}_{0}$ : There is no difference in average before and after the transfer of the capital of Israel to Jerusalem.

$\mathrm{H}_{1}$ : There are differences in the average before and after the transfer of the Israeli capital to Jerusalem.

The test statistic used in the hypothesis testing model using ANOVA is the F count value. The dependent variable (response) to be tested includes 3 (three) Indonesian macro economic indicators, namely the inflation rate, SBI interest rate and the exchange rate (exchange rate) of the rupiah against US \$. The results of model testing using the oneway ANOVA method for the three dependent variables (response) can be seen in Table 4.

Table 4

Oneway ANOVA Testing model

\begin{tabular}{clccccc}
\hline Variable & & Sum of Squares & df & $\begin{array}{c}\text { Mean } \\
\text { Square }\end{array}$ & F & Sig \\
\hline Inflation (\%) & Between Groups & 2,245 & 1 & 2,245 & 34,610 & 0.000 \\
& Within Groups & 1,427 & 22 & 0.065 & & \\
& Total & 3,672 & 23 & & & \\
\hline Interest Rate & Between Groups & 1,628 & 1 & 1.628 & 5,461 & 0.029 \\
SBI (\%) & Within Groups & 6,557 & 22 & 0.298 & & \\
& Total & 8,185 & 23 & & & \\
\hline Exchange & Between Groups & 593.590 & 1 & 593.590 & 13,007 & 0,002 \\
Rate Rupiah & Within Groups & 1.003 .991 & 22 & 45.636 & & \\
towards US\$ & Total & 1.597 .582 & 23 & & & \\
\hline
\end{tabular}

Source : Processed data research

Oneway ANOVA Testing model result for the three dependent variables (respons) as in Table 4 shows Indonesia's macro economic indicators, namely the SBI interest rate, the inflation rate and the exchange rate (exchange rate) of the rupiah against US \$. It can be concluded that there are differences in Indonesia's macro economic indicators before and after the transfer of the Israeli Capital to Jerusalem. This can be seen from the value of the significance level of $<0.05$ which means it produces a testing conclusion to reject $\mathrm{H} 0$.

- Inflation level, signicant level $=0.000<$ 0.05 , there are differences in averages

- SBI interest rates, significanct level $=0.029$ $<0.05$, there are differences in averages

- Exchange rates, significanct level $=0.002$ $<0.05$, there are differences in averages

The results above research conclssion that supports the research hypothesis, such 
as differences in the average on 3 (three) Indonesian macro economic indicators, SBI interest rates, inflation and the exchange rate (exchange rate) of rupiah against US \$ before and after the transfer of the Israeli Capital to Jerusalem.

\section{Discussion}

The United States government issued a foreign policy policy by recognizing Jerusalem as the capital of Israel. The policy was followed by the removal of the United States embassy from Tel Aviv to Jerusalem. President Trump's policy is getting a negative reaction from various countries such as China, Russia, Turkey, and countries that have been allies of the United States such as Britain and France are also opposing President Donald Trump's policies.

The United Nations in its resolution states that the status of Jerusalem to date is part of chaotic territory, which should not be owned by any country in the world. The conflicting parties in the region both Palestinian and Israeli are also not allowed to make claims that Jerusalem is their territory. So that President Trump's decision is contrary to the resolution issued by the United Nations. The Indonesian government also reacted negatively to the US policy. The Indonesian government expressed criticism of the US policy regarding the claim of Jerusalem as the Capital of Israel to further exacerbate the conflict that occurred in the region, especially the conflict between Palestine and Israel.

President Trump's policy sparked greater conflict in the region, and as a result will affect peace in the region. This Trump policy besides influencing in the context of foreign relations also affects the global economy. Conflicts in the Middle East region as well as previous conflicts always affect the global economy. The research results showed that the average inflation rate decrease after the transfer of the Israeli capital to Jerusalem. The inflation rate before transfer was 3.81\%, while the inflation rate after transfer was $3.20 \%$. The results above showed that there was deflation during the study period the Israeli capital moved to Jerusalem compared with before the transfer. Deflation referred to a decrease in the inflation rate. The transfer of the Israeli capital to Jerusalem has a positive impact on Indonesia's macro economy. The deflation in that period had a positive impact which caused a decline in commodity prices. The decreasing commodity prices will have an effect on people's purchasing power. The deflation will cause increasing people's purchase. The policy of moving the Israeli capital to Jerusalem proved to not push the inflation rate to be higher and even tended to decrease. This was due to Indonesia's economic fundamentals were still strong. One of them is reflected in the realization of the inflation rate after the transfer of the Israeli capital in Jerusalem is still within the target set by the government.

One of the economic issues that become concern to developing countries such as Indonesia is the problem of inflation. One indicator of a country's economic stability is the ability to control inflation. If a country is able to control the inflation rate it will drive the country's economic growth. Inflation problems are always related with the existence of social, political and economic turmoil that occurs inside or outside the country (Mankiw \& Gregory, 2007). (Panjai$\tan \&$ Wardoyo, 2016) states that one of the factors affecting the inflation rate is the SBI interest rate. Determination of interest rates high influence to reduce inflation pressure.

The research results showed the average SBI interest rate increased after the transfer of the Israeli capital to Jerusalem. The average SBI interest rate before the transfer of the Israeli capital to Jerusalem was $4.56 \%$, while the SBI interest rate after the transfer of the Israeli capital to Jerusalem was $5.08 \%$. Throughout 2018 after the transfer of the Israeli capital to Jerusalem, Bank Indo- nesia has raised the SBI interest rate by 150 basis points (bps) or $1.5 \%$. The BI governor explained that one reason for changing the benchmark interest rate was US monetary policy (Laucereno, 2018). 
The research results also showed the exchange rate (exchange rate) of the rupiah against US $\$$ after the transfer of the Israeli capital to Jerusalem was higher than before the transfer. The exchange rate (exchange rate) of the rupiah against US $\$$ before the transfer of the Israeli capital to Jerusalem was 10,237 , - per 1 US $\$$, while the exchange rate (exchange rate) of the rupiah against US \$ after the transfer of the capital of Israel to Jerusalem amounted to 10,551, - per 1 US \$. This means that the rupiah exchange rate against US \$ tends to weaker or happen Depreciation, after the transfer of the capital of Israel to Jerusalem compared to before the transfer of the Israeli capital to Jerusalem. However, the rate of rupiah depreciation against US \$ is not so big.

This condition showa the rupiah exchange rate against US $\$$ before and after the transfer of the Israeli capital to Jerusalem tended to be stable. Bank Indonesia has issued several policies to maintain the rupiah exchange rate against US \$. Bank Indonesia carried out several policies and interventions so that rupiah depreciation not too high.

One of the factors that influence the exchange rate (exchange rate) is the interest rate (Krugman, Obstfeld, Basri, \& Faisal, 2005). Long-term interest rate instruments will cause the rupiah is depreciated. According to (Sabirin, 2000) the factors that were the main causes of economic recovery came from the determined monetary policy.

Determination of appropriate and effective monetary policy will provide a formula for achieving exchange rate stability (exchange rate) and low inflation. Theoretically increasing interest rates will cause an increase in the exchange rate (exchange rate) against US \$. High interest rates will not provide a conducive climate for economic recovery, especially those related to exchange rates (Yudha \& Hadi, 2009).

The results of the study found that there were significant average differences for Indonesia's macro economic variables, namely the SBI interest rate, inflation and the exchange rate (exchange rate) of the rupiah against US $\$$ before and after the policy of transferring the Israeli capital to Jerusalem. These results can be seen from the one-way ANOVA test (Oneway ANOVA) for Indonesian macro economic variable indicators to conclude to reject Ho.

This means that the policy of transferring the Israeli capital to Jerusalem influences Indonesia's macro economic indicators. In this study indicators Indonesia's macro economy includes SBI interest rates, inflation and the exchange rate (exchange rate) of the rupiah against US \$. But Indonesia's relatively strong economic fundamentals have caused the Government of Indonesia to anticipate such policy changes so that it does not cause significant turmoil.

\section{CONCLUSSION AND SUGGESTION Conclussion}

The research conclusions are based on a study of data analysis and discussion as follows; (1) There is an influence on the transfer of the Israeli Capital to Jerusalem to the inflation rate; (2) There is an influence on the transfer of Israeli Capital to Jerusalem to the SBI rate; (3) There is an effect of transferring the Israeli capital to Jerusalem against; (4) the exchange rate of the rupiah against US \$

\section{Sugesstion}

To improve further research, the researchers provide suggestions as follows: (1) Dependent variable (response) needs to be developed with several other macro economic variables such as export volume, GDP or the amount of money in circulation; (2) Categories in independent variables (factors) need to be considered to be developed into more than 2 (two) categories so that more comprehensive conclusions can be obtained from the results of the study.

\section{REFERENCE}

Ali, T. M., Bashir, T., \& Mahmood, M. T. 2015. Impact of Interest Rate, Inflation and Money Supply on Exchange Rate Volatility in Pakistan. World Applied 
Sciences Journal 33(4): 620-630. doi: 10. 5829/idosi.wasj.2015.33.04.82

Asgharpur, Hossein, Kohnehshahri, Agheli, L., Karami, dan Azhdar. 2007. The Relationships between Interest Rates and Inflation Changes: an Analysis Of Long-Term Interest Rate Dynamics in Developing Countries. International Economic Conference on Trade and Industry (IECTI): 1-8.

Asnawi, dan Fitria, H. 2018. Pengaruh Jumlah Uang Beredar,Tingkat Suku Bunga Dan Inflasi Terhadap Pertumbuhan Ekonomi Di Indonesia. Ekonomika Indonesia VII(1): 24-32.

Bernanke, B. S., dan Kuttner, K. N. 2005. What Explains the Stock Market's Reaction to Federal Reserve Policy? The Journal of Finance 60(3): 1221-1257. doi: https://doi.org/10.1111/j.1540-6261. 2005.00760.x

Boediono. 2012. Seri Sinopsis Pengantar Ilmu Ekonomi 4.

Boediono. 2013. Seri Sinopsis: Pengantar Ilmu Ekonomi 4: i - 172. BPFE UGM. Yogyakarta.

Budimanta, A. 2017. Politik Amerika Bisa Ganggu Perekonomian Indonesia. Jawa Pos.

CaraHarian.com. 2019. Cara Menghitung Laju Inflasi dengan Tepat. Retrieved from https://caraharian.com/ekonomi /page/2.

Dwi, P. W. 2010. Analisis Pengaruh Faktor Fundamental Ekonomi Makro dan Harga Minyak Terhadap Saham LQ45 Dalam Jangka Pendek dan Panjang. Journal of Indonesia Applied Economics Universitas Brawijaya 4(1): 11-25.

Fadila, M. N. 2016 13. Kebijakan Donald Trump Mempengaruhi Perekonomian Indonesia dan Dunia. Kompasiana.

Fauzia, M. 2018. Kebijakan-Kebijakan Trump yang Mengguncang Ekonomi Global. Kompas.

Fischer, S., Lieberman, B. E., dan Adams, E. 1981. Macroeconomics. xiii - 738.
Fisher, I. 1930. The Theory of Interest Retrieved from http://files.libertyfund.org/ files/1416/0219_Bk.pdf

Harjanto, S. A. 2017. Bos BEI Khawatir Pernyataan Trump Ikut Guncang Pasar Modal RI CNN Indonesia.

Indonesia, B. (013) Informasi Kurs. from Copyright (C) 2013 Bank Indonesia https://www.bi.go.id/id/moneter/inf ormasi-kurs/Contents/Default.aspx

Jonathan. 2019. Rumus Perhitungan Berbagai Jenis Bunga Pinjama. Retrieved from https://koinworks.com/blog/ rumus-perhitungan-berbagai-jenisbunga-pinjaman

Jordaan, J. C. 2013. Impact of Interest Rate Changes on South African GDP and Households: A Combined Macroeconomic and Social Accounting Matrix Modelling Approach Southern African Business Review 17(3): 156-186.

Kandel, S., Ofer, A. R., dan Sarig, O. 1996. Real Interest Rates and Inflation: An ExAnte Empirical Analysis. The Journal of Financ 51(1): 205-225. doi: https://doi. org/10.1111/j.1540-6261.1996.tb05207.x

Kota, P. 2017. Kebijakan Pajak Donald Trump Berdampak Serius Bagi Ekonomi Indonesia. Pos Kota News.

Krugman, Obstfeld, P. R., Basri, M., dan Faisal. 2005. Ekonomi Internasional : Teori dan Kebijakan

Kwofie, C., dan Ansah, R. K. 2018. A Study of the Effect of Inflation and Exchange Rate on Stock Market Returns in Ghana. International Journal of Mathematics and Mathematical Sciences 2018: 1-8. doi: https://doi.org/10.1155/2018/7016792

Laucereno, S. F. 2018. Ini Alasan BI Naikkan Lagi Suku Bunga Acuan Jadi 5,75\%. detikFinance.

Linda, O. D. 2015. Pengaruh Suku Bunga SBI, Nilai Tukar Rupiah, dan Inflasi Terhadap Kinerja Keuangan Perusahaan Sebelum dan Sesudah Privatisasi (Studi Kasus Pada PT. Telekomunikasi Indonesia, Tbk). (S-1), Universitas Gunadarma, Depok-Jawa Barat. 
Retrieved from http://docplayer. info/ 30789567-Linda-dwi-oktavia-fakultasekonomi-universitas-gunadarmaabstract.html

Malik, K. Z., Ajmal, H., dan Zahid, M. U. 2017. Oil Price Shock and its Impact on the Macroeconomic Variables of Pakistan A Structural Vector Autoregressive Approach. International Journal of Energy Economics and Policy 7(5): 83-92.

Mankiw, dan Gregory, N. 2007. Macroeconomics 6.

Marshall, A. 2009. Principles of Economics

Mirzayev, E. 2019. Impact of the Chinese Economy on the U.S. Economy in 2018 Retrieved from https://www.investo pedia.com/articles/investing/072915/i mpact-chinese-economy-us-economy. asp.

Munawaroh, H., dan Handayani, S. R. 2019. Pengaruh BI Rate, Kurs Rupiah, Tingkat Inflasi, Harga Minyak Dunia, Harga Emas Dunia Terhadap Indeks Harga Saham Gabungan (IHSG). (Studi pada Perusahaan yang Terdaftar Di Bursa Efek Indonesia Periode 2013-2018). Jurnal Administrasi Bisnis (JAB) 72(1): 2736.

Mustami, A. A. 2017. BI jajaki 10 negara mitra dagang Indonesia lainnya. Kontan.co.id.

Muzakky, A., Suhadak, dan Topowijoyo. 2015. Pengaruh Inflasi, Tingkat Suku Bunga SBI, Pendapatan Per Kapita dan Ekspor Terhadap Nilai Tukar Rupiah dan Pertumbuhan Ekonomi

Studi Pada Bank Indonesia Periode Tahun 2002-2013. Administrasi Bisnis Universitas Brawijaya 23(1): 1-9.

Nopirin. 2007. Ekonomi Moneter.

Panjaitan, M. N. Y., dan Wardoyo. 2016. Faktor-Faktor yang mempengaruhi Inflasi di Indonesia. Jurnal Ekonomi Bisnis 21(3): 182-193.

Purnamawati, Ayu, I. G., dan Sri, W. D. N. 2013. Faktor Fundamental Ekonomi Makro Terhadap Harga Saham LQ 45. Jurnal keuangan dan perbankan Universitas Merdeka malang 17(2).
Rahmah, G. 2019. Apa Dampak Ledakan Kilang Minyak Aramco ke Ekonomi Indonesia? . Tempo.

Ronaldo, R. 2019. Pengaruh Inflasi dan Tingkat Pengangguran Terhadap Pertumbuhan Ekonomi Makro di Indonesia. (S3), Uni versitas Borobudur Jakarta. Jurnal Ekonomi. Retrieved from http://ejournal.borobudur.ac.id/index. php/1/article/view/555/546.

Rush, M. B., Hakkio, C. S., dan Schmidt, T. J. 1996. The Marginal Income Tax Rate Schedule From 1930 to 1990. Journal of Monetary Economics 38(1): 117-138. doi: 10.1016/0304-3932(96)01266-4.

Sabirin, D. S. 2000. Upaya Pemulihan Ekonomi Melalui Strategi Kebijakan Moneter-Perbankan dan Independensi Bank Indonesia Paper presented at the Seminar Nasional: "Strategi Pemulihan Ekonomi Era Pemerintahan Baru", KAGAMA Jawa Timur dan Perkumpulan untuk Peningkatan Usaha Kecil (PUPUK) https://www.google.com/search?clien $\mathrm{t}=$ firefox-b-d\&q=faktor+yang+menjadi +penyebab+utama+pemulihan+ekono mi+berasal+dari+kebijakan+moneter+y ang+ditetapkan

Samuelson, P. A., Nordhaus, W. D., dan Carvallo, B. 2004. Ilmu Makroekonomi.

Semuel, H., dan Nurina, S. 2015. Analysis of the Effect of Inflation, Interest Rates and Exchange Rates on Gross Domestic Product $(G D P)$ in Indonesia. Paper presented at the International Conference on Global Business, Economics, Finance and Social Sciences (GB15_Thai Conference) Bangkok Thailand.

Setiawan, S. R. D. 2018. Balas Trump, China Bakal Terapkan Tarif Impor untuk 128 Produk AS, Kompas.com. Retrieved from https://ekonomi.kompas.com/read/20 18/03/24/142356226/balas-trumpchina-bakal-terapkan-tarif-imporuntuk-128-produk-as

Simorangkir, E. 2017. Trump Akui Yerusalem Ibukota Israel, Ini Dampak Positifnya ke RI. detikFinance. 
Sugi. 2018. Pengertian Inflasi, Dampak Baik, dan Cara Menghadapinya. Retrieved from https://cpssoft.com/blog/keuangan/pengertian-inflasi-secaralengkap/

Winarto, Y., dan Quddus, G. G. 2017. Pemerintah Cermati Efek Trump Soal Yerusalem. Kontan.co.id.
Yudha, A. E., dan Hadi, S. 2009. Analisis Pengaruh Tingkat Suku Bunga SBI dan Volume Ekspor Impor Terhadap Nilai Tukar Rupiah. Jurnal Ekonomi Pembangunan 7(1): 48-62. doi: https://doi.org/10. 22219/jep.v7i1.3583. 